\title{
HUBUNGAN WAKTU KERJA TERHADAP HASIL KERJA PADA PELAKSANAAN UJI KOMPETENSI BIDANG PEMESINAN BUBUT DI SMK
}

\author{
Ito Ismanto ${ }^{1}$, Wardaya ${ }^{2}$, Purnawan ${ }^{3}$ \\ Departemen Pendidikan Teknik Mesin \\ Universitas Pendidikan Indonesia \\ Jl. Dr. Setiabudhi No. 207 Bandung 40154 \\ itoismanto@yahoo.co.id
}

\begin{abstract}
ABSTRAK
Pada pelaksanaan uji kompetensi kejuruan hasil penilaian aspek waktu kerja, semua siswa diberi nilai A atau skor 4 pada uji kompetensi kejuruan bidang pemesinan. Namun bila dilihat pada penilaian aspek hasil kerja apakah hasil kualitas geometriknya sesuai dengan soal uji kompetensi kejuruan. Apakah produk siswa pada uji kompetensi kejuruan bidang pemesinan dapat diprediksi dengan aspek waktu kerja. Tujuan dari penelitian ini, adalah untuk mengetahui seberapa besar hubungan waktu kerja terhadap hasil kerja pada uji kompetensi praktik kejuruan bidang pemesinan bubut di SMK Negeri 6 Bandung. Metode yang digunakan dalam penelitian ini adalah metode deskriptif korelasional dengan subjek penelitian sebanyak 30 siswa. Data dijaring melalui studi observasi secara langung pada pelaksanaan uji kompetensi praktik kejuruan teknik pemesinan untuk pekerjaan membubut. Hasil penelitian menunjukkan bahwa terdapat hubungan yang signifikan antara waktu kerja dengan hasil kerja pada uji kompetensi praktik kejuruan bidang pemesinan bubut.
\end{abstract}

Kata kunci: waktu kerja, hasil kerja, pemesinan, bubut, kompetensi.

\begin{abstract}
On the implementation of vocational competency test results of the assessment aspects of working time, all students are given A grades or a score of 4 at the machining field of vocational competency test. However, when viewed at valuation aspects of the work whether the result of geometric quality appropriate with the matter of vocational competency test. Whether the products of students at vocational competency test field machining can be predicted with aspects of working time. The purpose of this research was to determine how much the relationship of working time at vocational competency test practice field machining lathe at SMK Negeri 6 Bandung. The method used in this research is descriptive correlational method with a subject of research were 30 student. Data was captured through direct observation study at the implementation of vocational practice competency test to work a lathe machining techniques. The results showed that there is a significant relationship between work time with work result at the practice of vocational competency test lathe machining field.
\end{abstract}

Keywords: work time, work result, lathe, machining, Competence

\footnotetext{
${ }^{1}$ Mahasiswa Departemen Pendidikan Teknik Mesin FPTK UPI

${ }^{2}$ Dosen Departemen Pendidikan Teknik Mesin FPTK UPI

${ }^{3}$ Dosen Departemen Pendidikan Teknik Mesin FPTK UPI
} 


\section{PENDAHULUAN}

Pelaksanaan uji kompetensi merupakan salah satu standar kelulusan siswa di Sekolah Menengah Kejuruan (SMK). Tujuan dari penilaian kompetensi adalah untuk menetapkan keberhasilan peserta didik dalam menguasai satu unit kompetensi dengan mengacu kepada standar kompetensi nasional. Standar Kompetensi adalah kemampuan yang secara umum harus dimiliki oleh peseta didik (lulusan). Kompetensi adalah pernyataan yang menggambarkan penampilan suatu kemampuan tertentu secara bulat yang merupakan perpaduan antara pengetahuan dan kemampuan yang dapat diamati dan diukur (Hidayat, 2010). Hal tersebut sama dengan tujuan SMK yang mengacu pada isi undang-undang Sistem Pendidikan Nasional No. 20 Tahun 2003 pasal 3 mengenai tujuan pendidikan nasional dan penjelasan pasal 15 yang menyebutkan bahwa pendidikan kejuruan merupakan pendidikan menengah yang mempersiapkan peserta didik untuk bekerja dibidang tertentu.

Seorang siswa yang akan menjadi operator mesin di industri dituntut mampu untuk menghasilkan produk sesuai perencanaan dengan waktu yang telah ditentukan. Faktor-faktor yang mempengaruhi kualitas produk yaitu mesin/peralatan, pahat yang digunakan, bahan benda kerja, pemilihan parameter pemotongan, dan kemampuan siswa mengoperasikan mesin.

Parameter pemotongan untuk pekerjaan pemesinan bubut ada tiga yaitu kedalaman potong, gerak makan, dan kecepatan potong. Tiga parameter pemotongan tersebut adalah bagian yang dapat diatur langsung oleh seorang operator pada mesin bubut agar menghasilkan produk sesuai dengan perencanaan. Pemilihan parameter pemotongan ini berhubungan dengan waktu kerja dan umur pahat, jika waktu pemotongan terlalu cepat maka pahat akan cepat tumpul begitu pun dengan waktu pemotongan yang lama, pahat tidak akan cepat tumpul namun waktu pemesinan akan menjadi lama. Sehingga siswa harus melakukan perencanaan proses sebelum membubut.

Penilaian aspek waktu kerja pemesinan bubut, ternyata asesor memberikan nilai A atau skor 4 kepada semua siswa yang mengikuti uji kompetensi kejuruan teknik pemesinan tahun 2013/2014. Dapat dikatakan bahwa hasil pada penilaian aspek waktu uji kompetensi kejuruan tahun pelajaaran 2013/2014 telah sesuai dengan yang diharapkan oleh pihak sekolah (Karyadi, 2014). Namun bila dilihat pada penilaian aspek hasil kerja apakah hasil kualitas geometriknya sesuai dengan soal uji kompetensi kejuruan. Apakah produk siswa pada uji kompetensi kejuruan bidang pemesinan dapat diprediksi dengan aspek waktu kerja. 
Tujuan penelitian ini adalah untuk mengetahui gambaran hasil kerja produk pemesinan siswa dalam pelaksanaan uji kompetensi praktik kejuruan bidang pemesinan dan untuk mengetahui gambaran waktu kerja dan hasil kerja pada pelaksanaan uji kompetensi praktik kejuruan bidang pemesinan bubut. Selain itu untuk mengetahui hubungan antara waktu kerja terhadap hasil kerja proses pemesinan pekerjaan membubut dalam pelaksanaan uji kompetensi kejuruan bidang pemesinan di SMK Negeri 6 Bandung. Dalam penelitiannya melakukan pengumpulan data dengan cara mengukur produk hasil kerja uji kompetensi praktek, menggunakan jangka sorong analog dengan ketelitian $0.05 \mathrm{~mm}$ untuk mengetahui dimensi produk hasil kerja berupa ketepatan ukuran dengan toleransi yang ditentukan.

\section{METODE PENELITIAN}

Penelitian ini menggunakan metode deskriptif korelasional. Tujuan untuk memaparkan hasil penelitian pada setiap variabel dan menghasilkan temuan berupa tingkat hubungan antara variabel tersebut. Fokus penelitian pada waktu pemesinan dengan hasil geometrik pada bidang pemesinan bubut. Populasi penelitian ini adalah seluruh siswa tingkat XII pada kompetensi keahlian bidang pemesinan di SMK Negeri 6 Bandung tahun pelajaran 2013/2014 yang terdiri atas empat kelas dengan jumlah siswa sebanyak 120 siswa. Adapun teknik sampel yang digunakan adalah sampling insidental, sampling insidental teknik ini adalah menentukan sampel berdasarkan kebetulan. Siapa saja yang secara kebetulan/incidental bertemu dengan peneliti dapat digunakan sebagai sampel. Bila dipandang orang yang kebetulan ditemui itu cocok sebagai sumber data. Sampel yagn digunakan berjumlah 30 siswa.

\section{HASIL PENELITIAN}

Adapun data waktu pemesinan hasil uji kompetensi pekerjaan membubut diperoleh sebagai berikut:

Tabel 1. Waktu kerja uji kompetensi kejuruan bidang pemesinan bubut

\begin{tabular}{lc}
\hline \multicolumn{1}{c}{ Data } & Waktu Kerja (menit) \\
\hline Waktu Maksimum & 390 \\
\hline Waktu Minimum & 85 \\
\hline Waktu rata-rata & 213 \\
\hline Standar Deviasi & 57 \\
\hline
\end{tabular}


Data tersebut merupakan gambaran umum mengenai waktu kerja pada uji kompetensi praktik kejuruan bidang pemesinan bubut, yang terdiri dari waktu kerja maksimum, waktu kerja minimum dan waktu kerja rata-rata. Waktu maksimum atau waktu terlama yaitu 390 menit, kemudian waktu tercepat atau waktu minimal adalah 85 menit, waktu rata-rata penyelesaian produk dalam proses pembubutan adalah 213 menit dan standar deviasi untuk waktu kerja yaitu 57.

Tabel 2. Hasil kerja uji kompetensi kejuruan bidang pemesinan bubut

\begin{tabular}{lc}
\multicolumn{1}{c}{ Data } & Hasil Kerja \\
\hline Nilai Maksimum & 27 \\
\hline Nilai Minimum & 8 \\
\hline Nilai rata-rata & 16,7 \\
\hline Standar Deviasi & 5,18 \\
\hline
\end{tabular}

Data tesebut merupakan gambaran umum mengenai hasil kerja pada uji kompetensi praktik kejuruan bidang pemesinan bubut, yang terdiri dari nilai maksimum, nilai minimum dan nilai rata-rata. Nilai maksimum yaitu 27 , kemudian nilai minimal adalah 8 , nilai rata-rata hasil produk dalam proses pembubutan adalah 16,7 dan standar deviasi untuk hasil kerja yaitu 5,18. Tabel 3 adalah hasil analisis data yang telah dihitung. Pada penelitian ini, dilakukan analisis data yang meliputi uji normalitas, perhitungan koefisien korelasi, serta pengujian hipotesis.

Tabel 3 Hasil Analisis Data

\begin{tabular}{|c|c|c|c|}
\hline \multirow{2}{*}{\multicolumn{2}{|c|}{ Data Penelitian }} & \multicolumn{2}{|c|}{ Hasil Uji Kompetensi kejuruan } \\
\hline & & $\begin{array}{l}\text { Waktu Kerja } \\
(\mathrm{X})\end{array}$ & $\begin{array}{c}\text { Hasil Kerja } \\
(\mathrm{Y})\end{array}$ \\
\hline \multirow[t]{2}{*}{ Uji Normalitas } & Nilai $\chi^{2}$ & $\begin{array}{l}\chi_{\text {hitung }}^{2} \leq \chi_{\text {tabel }}^{2} \\
(84,3 \geq 11,07)\end{array}$ & $\begin{array}{l}\chi_{\text {hitung }}^{2} \leq \chi_{\text {tabel }}^{2} \\
(79,44 \geq 11,07)\end{array}$ \\
\hline & Kondisi & Tidak Normal & Tidak Normal \\
\hline \multirow{2}{*}{$\begin{array}{l}\text { Perhitungan Koefisien } \\
\text { Korelasi }\end{array}$} & Nilai $\mathrm{r}$ & \multicolumn{2}{|c|}{$\mathrm{r}=0,319$} \\
\hline & $\begin{array}{l}\text { Tingkat } \\
\text { Hubungan }\end{array}$ & \multicolumn{2}{|c|}{ Rendah } \\
\hline \multirow{2}{*}{ Pengujian Hipotesis } & Nilai t & \multirow{2}{*}{\multicolumn{2}{|c|}{$\frac{\mathrm{t}_{\text {hitung }}=1,883 \geq \mathrm{t}_{\text {tabel }}=1,701}{\text { Ho ditolak dan Ha diterima }}$}} \\
\hline & Kondisi & & \\
\hline
\end{tabular}

Uji normalitas data dilakukan untuk mengetahui apakah data yang diperoleh terdistribusi normal atau tidak. Berdasarkan hasil uji normalitas data waktu kerja dan hasil kerja menunjukkan bahwa data waktu kerja $84,3 \geq \chi_{\text {tabel }}^{2} 11,07$, data waktu kerja tidak 
terdistribusi normal dan hasil kerja $79,44 \geq \chi^{2}$ tabel 11,07 , data hasil kerja tidak terdistribusi normal. Kedua data hasil uji normalitas antara waktu kerja dan hasil kerja, tidak terdistribusi normal maka penelitian ini mengacu pada penelitian non-parametrik.

Uji koefisien korelasi dilakukan untuk mengetahui tingkat hubungan antara waktu kerja uji kompetensi kejuruan bidang pemesinan dengan hasi kerja uji kompetensi kejuruan bidang pemesinan. Berdasarkan hasil analisis data yang telah dilakukan, diperoleh harga koefisien korelasi sebesar 0,319. Harga koefisien korelasi tersebut diinterpretasikan ke dalam Tabel untuk mengetahui tingkat hubungan yang terjadi. Berdasarkan hasil perhitungan koefisien korelasi, diketahui bahwa harga koefisien korelasi yang ditemukan sebesar 0,319 berada pada kategori rendah. Sehingga terdapat hubungan yang rendah antara waktu kerja dengan hasil kerja pada uji kompetensi kejuruan bidang pemesinan.

Hasil perhitungan yang telah dilakukan, diperoleh harga $t_{\text {hitung }}$ sebesar 1,883 dan $t_{\text {tabel }}$ sebesar 1,701 dengan $\mathrm{dk}=28$ dan taraf kesalahan atau taraf signifikansi $(\alpha)$ sebesar 5\%. Dikarenakan harga $t_{\text {hitung }}$ lebih besar daripada harga $t_{\text {tabel }}$, dengan kata lain bahwa harga $t_{\text {hitung }}$ berada di daerah penolakan Ho, maka Ho ditolak dan Ha diterima. Sehingga hipotesis yang diterima yaitu terdapat hubungan yang signifikan antara waktu kerja dengan hasil kerja uji kompetensi praktek kejuruan bidang pemesinan. Hasil penelitian menunjukkan nilai hasil kerja pada pelaksanaan uji kompetensi praktik kejuruan bidang pemesinan bubut didapat nilai hasil kerja minimal adalah 8 dan nilai hasil kerja maksimal adalah 27 . Total nilai hasil kerja tersebut didapatkan nilai hasil kerja rata-rata sebesar 16.

\section{PEMBAHASAN}

Data yang diperoleh dikelompokkan ke dalam lima kategori penilaian pada aspek waktu kerja. Sebanyak 13\% Siswa yang mendapatkan kategori sangat cepat, sama halnya pada kategori cepat sebanyak 13\%, siswa yang berada dikategori sedang sebanyak 43\%, untuk kategori lambat sebanyak $24 \%$ dan untuk kategori sangat lambat sebanyak $7 \%$. Distribusi data mengenai waktu kerja pada pelaksanaan uji kompetensi praktik kejuruan bidang pemesinan bubut, yang ditunjukan pada Tabel 4. 
Tabel 4. Waktu kerja pada uji kompetensi kejuruan bidang pemesinan bubut

\begin{tabular}{cccccc}
\hline No & Kategori & Kriteria & Rentang & Frekuensi & $\%$ \\
\hline 1 & Sangat cepat & $\mathrm{A} \leq \overline{\mathrm{X}}-\mathrm{SD}$ & $\mathrm{A} \leq 156$ & 4 & 13 \\
2 & Cepat & $\overline{\mathrm{X}}-\mathrm{SD}<\mathrm{B} \leq \overline{\mathrm{X}}-\frac{1}{2} S D$ & $156<\mathrm{B} \leq 184,5$ & 4 & 13 \\
3 & Sedang & $\mathrm{X}-\frac{1}{2} S D<\mathrm{C} \leq \overline{\mathrm{X}}+\frac{1}{2} \mathrm{SD}$ & $184,5<\mathrm{C} \leq 241,5$ & 13 & 43 \\
4 & Lambat & $\overline{\mathrm{X}}+\frac{1}{2} \mathrm{SD}<\mathrm{D} \geq \overline{\mathrm{X}}+\mathrm{SD}$ & $241,5<\mathrm{D} \leq 270$ & 7 & 24 \\
5 & $\begin{array}{c}\text { Sangat } \\
\text { lambat }\end{array}$ & $\mathrm{E}>\overline{\mathrm{X}}+\mathrm{SD}$ & $\mathrm{E}>270$ & 2 & 7 \\
\hline \multicolumn{7}{c}{ Jumlah }
\end{tabular}

Hasil ini menunjukan bahwa kriteria pencapaian kompetensi siswa pada penilaian aspek waktu kerja belum tercapai dengan baik. Rata-rata siswa berada pada interval kategori sedang. Keterampilan siswa dalam melakukan pekerjaan praktik kejuruan ini belum mumpuni dan menggambarkan hasil pencapaian belajar yang kurang baik. Banyak faktor yang mempengaruhi ketidaktercapaian penilaian waktu kerja secara maksimal.

Faktor yang mempengaruhi waktu pemesinan diantaranya kedalaman pemotongan, gerak makan, kecepatan potong, ketajaman pahat dan kemampuan operator dalam mengoprasikan mesin. Siswa dituntut untuk menghasilkan produk sesuai dengan perencanaan dengan waktu yang telah ditentukan. Jika pada proses pemesinan terlalu lama, maka akan berpengaruh pada umur pahat. Pahat akan tumpul dan hal itu akan berpengaruh pada kualitas produk, seperti kualitas produk yang jadi menurun.

Tiga parameter utama pada setiap proses bubut adalah kecepatan putar, gerak makan, dan kedalaman potong (Widarto, 2008). Faktor yang lain seperti bahan benda kerjadan jenis pahat sebenarnya juga memiliki pengaruh cukup besar, tetapi tiga parameter di atas adalah bagian yang bisa diatur oleh operator langsung pada mesin bubut. Kecepatan putar n (speed), selalu dihubungkan dengan sumbu utama (spindel) dan benda kerja. Kecepatan dinotasikan sebagai putaran per menit (rotations per minute). Gerak makan, f (feed), adalah jarak yang ditempuh oleh pahat setiap benda kerja berputar satu kali. Gerak makan ditentukan berdasarkan kekuatan mesin, material benda kerja, material pahat, bentuk pahat, dan terutama kehalusan permukaan yang diinginkan. Gerak makan biasanya ditentukan dalam hubungannya dengan kedalaman potong. Gerak makan tersebut berharga sekitar 1/3 sampai 1/20 kedalaman 
potong, atau sesuai dengan kehalusan permukaan yang dikehendaki. Kedalaman potong, a (depth of cut) adalah tebal bagian benda kerja yang dibuang dari benda kerja, atau jarak antara permukaan yang dipotong terhadap permukaan yang belum dipotong. Hasil perhitungan mengenai hasil kerja pada pelaksanaan uji kompetensi praktik kejuruan bidang pemesinan bubut, dapat dilihat pada Tabel 5 .

Tabel 5. Hasil kerja pada uji kompetensi kejuruan bidang pemesinan bubut

\begin{tabular}{cccccc}
\hline No & Kategori & Kriteria & Rentang & Frekuensi & $\%$ \\
\hline 1 & Sangat Bagus & $\mathrm{A} \geq \overline{\mathrm{X}}+\mathrm{SD}$ & $\mathrm{A} \geq 21,9$ & 4 & 13 \\
2 & Bagus & $\overline{\mathrm{X}}+\mathrm{SD}>\mathrm{B} \geq \overline{\mathrm{X}}+\frac{1}{2} \mathrm{SD}$ & $21,9>\mathrm{B} \geq 19,3$ & 6 & 20 \\
3 & Sedang & $\overline{\mathrm{X}}+\frac{1}{2} \mathrm{SD}>\mathrm{C} \geq \overline{\mathrm{X}}-\frac{1}{2} \mathrm{SD}$ & $19,3>\mathrm{C} \geq 14,3$ & 8 & 27 \\
4 & Jelek & $\overline{\mathrm{X}}-\frac{1}{2} \mathrm{SD}>\mathrm{D} \geq \overline{\mathrm{X}}-\mathrm{SD}$ & $14,3>\mathrm{D} \geq 11,5$ & 5 & 17 \\
5 & Sangat Jelek & $\mathrm{E}<\overline{\mathrm{X}}-\mathrm{SD}$ & $\mathrm{E}<11,5$ & 7 & 23 \\
\hline \multicolumn{7}{c}{ Jumlah }
\end{tabular}

Data dikelompokkan ke dalam lima kategori penilaian pada aspek hasil kerja. Siswa yang mendapatkan kategori sangat bagus sebesar 13\%, siswa masuk kategori bagus sebanyak 20\%, yang mendapat kategori sedang sebesar 27\%, 17\% mendapat kategori jelek, dan pada kategori sangat jelek sebesar 23\%. Pada a aspek hasil kerja lebih banyak siswa yang berada pada kategori sangat jelek dibandingkan dengan aspek waktu kerja.

Sama halnya dengan waktu kerja, distribusi data hasil kerja pada gambar 2 menunjukan hasil bahwa kriteria pencapaian kompetensi siswa pada penilaian aspek hasil kerja belum tercapai dengan baik. Pada penilaian yang telah dilakukan oleh penulis, terdapat 7 orang siswa atau $23 \%$ siswa yang berada dikategori sangat jelek. Hasil tersebut apakah lulusan SMK mampu bersaing di dunia industri. Jika pada kenyataannya banyak lulusan SMK tidak terserap di industri, maka akan semakin banyak pengangguran.

Dilihat dari penilaian Badan Standar Nasional Pendidikan (BSNP), hasil kerja pada uji kompetensi kejuruan bidang pemesinan bubut memiliki bobot $40 \%$, bobot hasil kerja merupakan bobot yang tertinggi dibandingan aspek-aspek yang lain. Jika nilai pada aspek hasil kerja berada pada kategori sangat jelek, maka akan berpengaruh besar terhadap nilai aspek-aspek yang lainnya. Sejauh ini lulusan yang kompeten oleh pihak penyelenggara uji kompetensi praktik kejuruan kurang relevan dan dinilai kurang kompeten bila dilihat dari hasil perhitungan yang dilakukan oleh penulis. 
Adapun faktor lain yang mempengaruhi kualitas geometri produk hasil kerja yaitu mesin produksi presisi (tepat, atau keterulangan tinggi) biasanya akan mempunyai karateristik variabilitas (keadaan bervariasi kecenderungan berubah-rubah) proses yang kecil namun sebaliknya mesin produksi yang tidak presisi (serta tidak otomatik) cenderung untuk menghasilkan produk dengan variabilitas yang besar (Rochim, 2001). Hal inilah yang menyebabkan kualitas produk hasil kerja menjadi tidak maksimal dan sering tidak diperhatikan oleh siswa maupun guru praktikan yang ada disekolah.

Hubungan yang diperoleh berdasarkan hasil analisis data mengenai uji koefisien korelasi spearman dan uji hipotesis, dikategori rendah. Setelah dilakukan perhitungan koefisien korelasi spearman diperoleh hasil $\mathrm{rho}_{\mathrm{xy}}=0,319$. Artinya bahwa terdapat hubungan antara waktu kerja dengan hasil kerja namun hubungan tersebut rendah. Ini menunjukan bahwa aspek waktu kerja bisa digunakan untuk memprediksi hasil produknya namun hubungannya rendah. Ini dikarena pada penilaian uji kompetensi kejuruan terdapat penilaian aspek-aspek yang lain yang mempangaruhi hasil uji kompetensi, seperti persiapan kerja, proses, dan sikap kerja. Selain pada penilaian uji kompetensi, kemampuan siswa mengoperasikan mesin sangat mempengaruhi waktu kerja dan hasil kerja. Faktor lain yang dilakukan oleh operator pahat yang digunakan tidak sesuai dengan pekerjaan dilakukan, yang dipandang dari segi materialnya maupun geometriknya (bentuk dan sudut pahat). Berdasarkan faktor-faktor tersebut, seorang operator harus bisa merencanakan/mengoptimasi proses pemesinan agar mendapatkan kualitas geometri pada dimensi yang sesuai dengan gambar kerja.

Hasil perhitungan hipotesis, diperoleh harga $t_{\text {hitung }}$ lebih besar daripada harga $t_{\text {tabel }}$. Diperoleh bahwa terdapat hubungan yang signifikan antara waktu kerja dengan hasil kerja pada pelaksanaan uji kompetensi praktk kejuruan bidang pemesinan bubut. Walaupun pada perhitungan koefisien korelasi berada dikategori rendah, tetapi pada uji hipotesis hubungannya signifikan. Aspek waktu bisa digunakan untuk memprediksi hasil produk karena ada hubungan yang signifikan walaupun rendah. Sehingga Aspek waktu tidak bisa diabaikan dalam mempengaruhi kualitas produk karena hubungannya signifikan. Selain waktu yang mempengaruhi kualitas produk adapun faktor lain yaitu kompetensi siswa. Kompetensi, yaitu suatu pengetahuan, keterampilan, dan kemampuan atau kapabilitas yang dimiliki oleh seseorang yang telah menjadi bagian dari dirinya sehingga mewarnai perilaku kognitif, afektif, 
dan psikomotor (Sanjaya, 2011). Sehingga berdasarkan pendapat tersebut, jelas bahwa suatu kompetensi tidak akan pernah muncul dari diri siswa, apabila tidak didukung oleh pengetahuan, sikap, dan keterampilan.

Implikasi dari pembahasan hasil penelitian yang dilakukan adalah aspek waktu perlu diperhatikan oleh siswa, seorang siswa yang akan melakukan uji kompetensi kejuruan harus melakukan analisis proses terlebih dahulu, sehingga dapat mengetahui waktu standar untuk menghasilkan produk yang bagus atau sesuai perencanaan. Jika hasil produk itu kurang bagus maka, waktu pemesinan yang tidak sesuai dengan pengerjaan produk.

\section{KESIMPULAN}

Kesimpulan penelitian dapat dinyatakan bahwa waktu kerja pada uji kompetensi kejuruan bidang pemesinan bubut menunjukkan kategori atau predikat baik. Hasil kerja pada uji kompetensi kejuruan bidang pemesinan bubut menunjukkan pada kategori atau predikat baik. Terdapat hubungan yang signifikan antara waktu kerja dengan hasil kerja uji kompetensi praktik kejuruan bidang pemesinan bubut .

\section{DAFTAR PUSTAKA}

Badan Standar Nasional Pendidikan. (2013). Lembar Penilaian Ujian Praktik Kejuruan Tahun Pelajaran 2013/2014. Jakarta: Depdiknas.

Karyadi, A. (2014). Analisis Waktu Pemesinan pada Uji Kompetensi Praktik Kejuruan Teknik Pemesinan di SMK Negeri 6 Bandung. Skripsi Sarjana pada FPTK UPI Bandung: tidak diterbitkan.

Hidayat, D. (2010). Studi Komparasi Siswa SMK Menggunakan Jobsheet Pemesinan Bubut Hasil Pengembangan dengan Jobsheet Pemesinan Bubut yang digunakan Guru. Skripsi Sarjana pada FPTK UPI Bandung: Tidak Diterbitkan.

Rochim, T. (2001). Spesifikasi, Metrologi, \& Control Kualitas Geometrik. Bandung: ITB.

Sanjaya, W. (2011). Pembelajaran dalam Implementasi Kurikulum Berbasis Kompetensi. Jakarta: Kencana.

Widarto. (2008). Teknik Pemesinan untuk SMK. Jakarta: Diektorat Pembinaan Sekolah Menengah Kejuruan. 